\title{
Adult Mediastinal Cystic Hygroma: A Case Report
}

\author{
Yetişkinde Mediastinal Kistik Higroma: Olgu Sunumu
}

Hülya Dirol ${ }^{1}$, Fatma Deniz ${ }^{1}$, Aykut Çilli' ${ }^{1}$, Levent Dertsiz ${ }^{2}$

\begin{abstract}
Cystic hygroma is an uncommon congenital malformation of the lymphatic system that is composed of dilated and fluid-filled lymphatic vessels. It is thought to occur due to a blockage in the lymphatic system during the developmental stage. Most are located in the neck, although they can also present in the axilla and mediastinum. Isolated mediastinal cystic hygroma is a very rare pathology in adults, with complete surgical excision being the treatment of choice. The lesion and the surrounding tissue must be fully resected due to the high recurrence rates associated with incomplete resections. In cases where a total excision is impossible, radiotherapy, aspiration, sclerosing injections, systemic chemotherapy and interferon- $\alpha$ are the other treatment options. Here, we report on a case with an incidentally detected mediastinal cystic hygroma, presenting the results of a four-year follow up after a complete resection.
\end{abstract}

Key words: Cystic hygroma, mediastinal cystic lesion, lymphatic system developmental anomaly, congenital benign lymphatic system neoplasm.

\section{Özet}

Kistik higroma, lenfatik sistemin nadir görülen konjenital bir malformasyonudur ve genişlemiş ve sıvı dolu lenfatik damarlardan oluşur. Oluşum sırasında lenfatik sistemde meydana gelen tıkanma nedeniyle geliştiği varsayılmaktadır. Çoğu boyunda bulunur, ancak aksilla ve mediastende de bulunabilirler. Erişkinlerde izole mediastinal kistik higroma çok nadir görülen bir patolojidir. Tam cerrahi eksizyon, tercih edilen tedavi yöntemidir. Yüksek nüks oranları nedeniyle inkomplet eksizyon yerine lezyon ve çevresindeki dokunun tamamen rezeke edildiği komplet eksizyon tercih edilir. Eksizyonun imkansız olduğu durumlarda radyoterapi, aspirasyon, sklerozan enjeksiyonu, sistemik kemoterapi ve interferon- $\alpha$ gibi diğer tedavi yöntemleri uygulanabilir. Burada, tesadüfen saptanan bir mediastinal kistik higroma olgusunu ve tam rezeksiyondan sonra 4 yıllık takip sonuçlarını sunuyoruz.

Anahtar Sözcükler: Kistik Higroma, mediastinal kistik lezyonlar, lenfatik sistem gelişimsel anomalileri, konjenital lenfatik sistem neoplazmları.

'Department of Pulmonology, Akdeniz University Faculty of Medicine, 'Akdeniz Üniversitesi Tıp Fakültesi, Göğüs Hastalıkları AnaAntalya, Turkey

${ }^{2}$ Department of Thoracic Surgery, Akdeniz University Faculty of bilim Dalı, Antalya

${ }^{2}$ Akdeniz Üniversitesi Tıp Fakültesi, Göğüs Cerrahisi Anabilim Medicine, Antalya, Turkey Dalı, Antalya

Submitted (Başvuru tarihi): 22.04.2019 Accepted (Kabul tarihi): 12.07.2019

Correspondence (iletişim): Hülya Dirol, Department of Pulmonology, Akdeniz University Faculty of Medicine, Antalya, Turkey

e-mail: hulyadirol@akdeniz.edu.tr 
Cystic hygroma is a benign developmental anomaly of the lymphatic tissue. It can be encountered at any age, but is most common in childhood (1). The most frequently effected sites are the head and neck (2). The clinical presentation is related closely to the lesion's anatomical localization. Mediastinal cystic hygromas present with symptoms of airway compression and signs of pulmonary hypoplasia in early childhood. In most cases they remain undetected for many years due to the slow growth and absence of symptoms, and are diagnosed incidentally during radiological evaluations of the chest for other reasons (3). In a computerized thorax tomography (CAT), a typical finding is a mediastinal cystic lesion, although radiological appearance is not enough for diagnosis as other mediastinal cystic lesions, such as thymic cysts, bronchogenic cysts, pericardial cysts, pulmonary ecchinococcus, Castleman's disease, cystic teratoma. Diagnosis requires a histopathologic examination of the resected specimen. The optimum treatment method is the total surgical excision of the mass and the surrounding tissue (4), as in cases of incomplete resection recurrences often occur. Prognosis is good in all complete resections. In cases where a total excision is impossible, radiotherapy, aspiration, sclerosing injections, systemic chemotherapy and interferon- $\alpha$ are accepted as other applicable treatment options. Here, we report on a rare case of an isolated mediastinal cystic hygroma in an adult patient with clinical, radiological and histopathological features, and the four-year follow up results.

\section{CASE}

A 46-year-old male patient admitted to our hospital with abnormal radiological findings that were encountered incidentally during a job application. The patient reported no respiratory complaints. The patient's medical history contained no operations, no trauma and no serious infection. The patient had no comorbidity and had never taken drugs. There was no occupational exposure, no animal feeding at home and no travel history. He was a current smoker with a 30 pack/year smoking history. His family history was unremarkable. The results of physical examinations of all organ systems were totally normal. Blood test results were as follows: $\mathrm{Hb}$ : 13.9, Hct: 43.5, Leucocytes: 7,940 / mm³ , Platelet: 216,000 / mm³, serum $C$ reactive protein (CRP): $2.74 \mathrm{mg} / \mathrm{L}, \mathrm{ALT}: 14$ and Creatinin: 0.74 . A PA chest radiography revealed a radio-opacity in the right hemi-thorax, superimposing the shadow of the superior vena cava just to the right of the trachea (Figure 1). The margins were well demarcated and $73.1 \times 43.7 \mathrm{~mm}$ in diameter. A chest CT revealed a $75 \times 45 \mathrm{~mm}$ multi-lobulated cystic mediastinal mass with no invasion or compression of the nearby structures (Figure 2). A total surgical excision of the mass was the preferred method for both diagnosis and treatment. A right lateral thoracotomy to excise the right paratracheal cystic lesion was performed, and a lesion with a transparent wall that was filled with a serous fluid was fully excised. In a microscopic evaluation, CD34, CD31, Pan-CK, CK5/6, calretinin, CD5 and CD20 stains were applied, and no other finding was present other than dilated lymphatic vessels, leading to a diagnosis of cystic hygroma (Figure 3). There were no complications after the surgery and no relapse within a four-year follow up (Figure 4).

\section{DISCUSSION}

Cystic hygroma is a benign developmental anomaly of the lymphatic tissue consisting of many cystic structures that extend into the surrounding tissues (5). The cystic structure is lined with vessel endothelium and filled with lymphatic fluid (6). The most likely hypothesis related to its genesis is that it is a developmental anomaly of the fetal lymphatic sacs, with no link to the central lymphatic or venous system. The reason for this disintegration has yet to be understood, and whether it is genetic or infectious, or whether the disintegration is congenital or acquired. Our patient had no family history and no infection history, either intrauterine or during the infantile period.

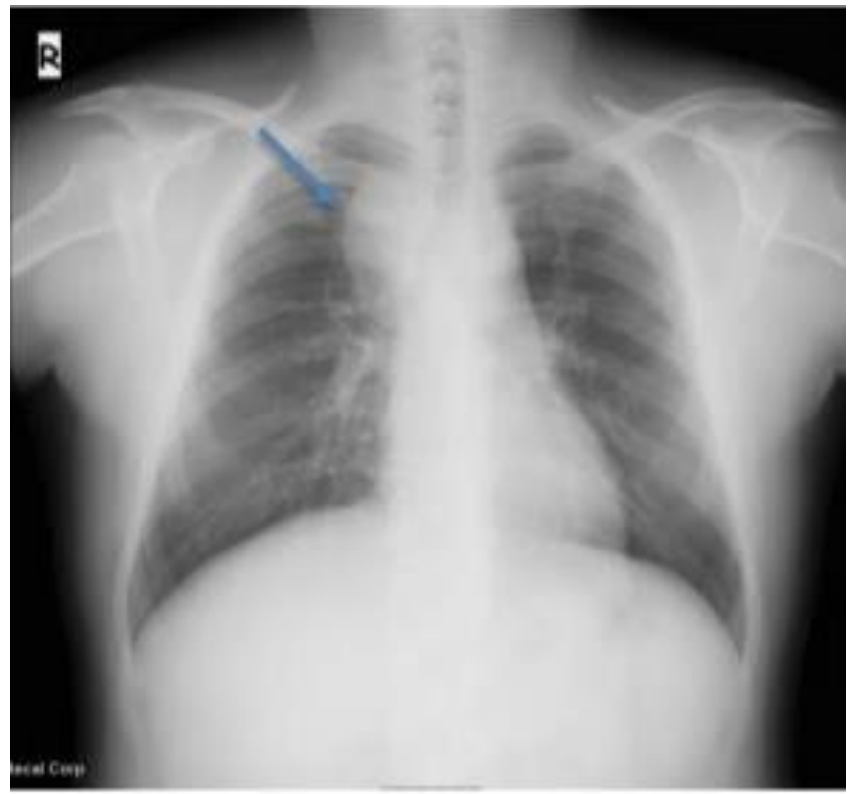

Figure 1: PA chest radiography revealed a radio-opacity in the right hemithorax, superimposing the shadow of superior vena cava, just right of the trachea 
According to the predicted theory about its genesis, it can arise in any location of the body where lymphatic vessels are present, but the most common sites are the head and neck. Other sites reported in literature are the mediastinum, chest wall, axilla, liver, spleen, pancreas, colon, bones and genital organs (7). Most cystic hygromas are noticed early and diagnosed during childhood, and often before the age of 2 years, one reason for which is that the most common development sites are easily appreciable body parts, like the neck. Hygromas that arise from the lymphatic channel of the thorax or the abdomen are diagnosed later in life. The slow progression of the lesion can mean it remains unnoticed for many years, and most come to light by chance during radiological evaluations for other reasons, as in our case.

Cystic hygromas constitute 7 percent of all mediastinal masses (8). Most patients with a mediastinal cystic hygroma are asymptomatic due to the previously mentioned reasons, but symptoms such as dyspnea, cough, chest pain, dysphagia and hoarseness due to vocal cord paralysis are possible due to the compression of the cystic mass over the nearby structures (9).

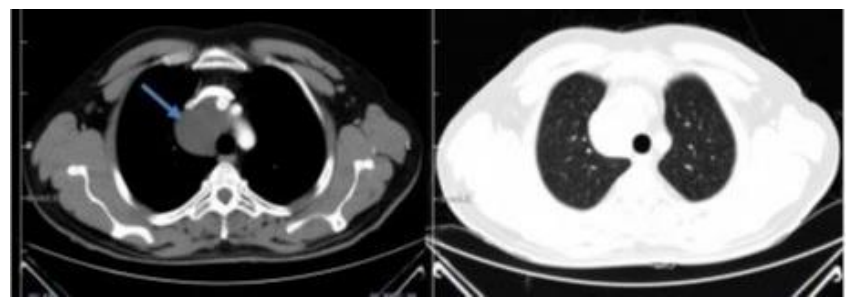

Figure 2: The margins of the lesion were well demarcated and 73. $1 \times 43.7 \mathrm{~mm}$ in diameter. A chest CT identified a $75 \times 45 \mathrm{~mm}$ multilobulated cystic mediastinal mass with no invasion or compression on the nearby structures

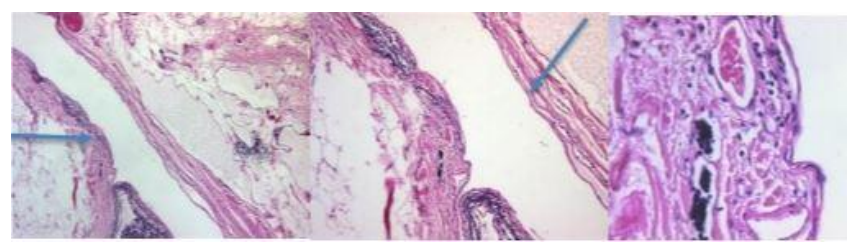

Figure 3: CD34, CD31, PanCK, CK56, calretinin, CD5 and CD20 stains; dilated lymphatic vessels marked by the blue arrow

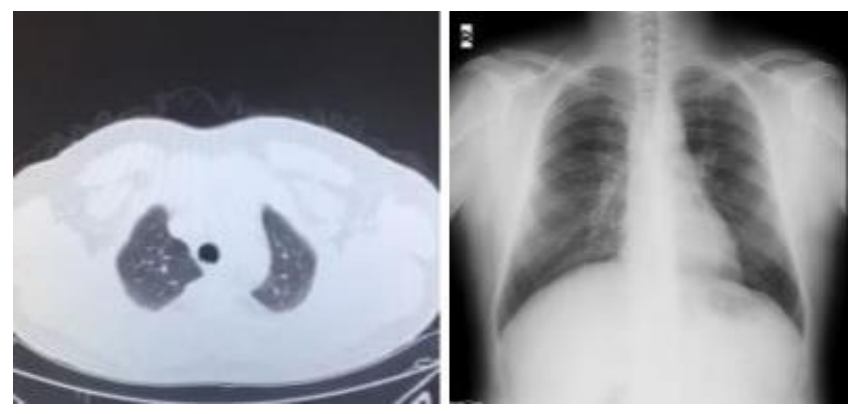

Figure 4: No relapse within a four-year follow up
A typical radiological finding of a mediastinal cystic hygroma is a cystic lesion, usually in the anterior mediastinum. The cystic image is a result of the low density of the fluid in the inner site, though it may sometimes be perceived as a solid lesion rather than cystic if the inner site of the lesion is filled with hemorrhage, a high amount fat or protein that increases the density (10). Magnetic resonance imaging is the most sensitive radiological technique for the evaluation of the inner structure and the dimensions of the lesion, as well as its relationship with the near tissues, vessels and organs (11).

The preferred treatment is total surgical excision, although some people prefer a conservative approach in asymptomatic patients. No malign transformation has been reported, but even small and asymptomatic hygromas cannot be dismissed, as infection of the cyst or hemorrhage inside the cyst, or sudden rapid increases in size can occur and harm the patient. It is very rare for a cystic hygroma to resolve spontaneously, and so the mass must be resected completely whenever it is faced. The traditional approach to total excision is via a thoracotomy, although successful results have been reported with VATS in mediastinal cystic hgyromas (12). In incomplete resections, recurrence rates are very high (13), with an average recurrence time of 3 months post operation, although long-term follow up is recommended as recurrences have been reported even after 7 years (14). Prognosis is good in all complete resections. In cases where a total excision is impossible due to the location of the lesion, or where surgery is contraindicated due the other medical problems, chemotherapy, radiotherapy, sclerosing injection (100\% ethanol, bleomycin, OKT-432) and interferon- $\alpha$ are feasible treatment modalities with limited and variable efficiency (15-17). In the presented case, we opted for a total resection of the cystic hygroma, even though it was small and the patient was asymptomatic. No operation complications were experienced and the patient, we are happy to say, has remained disease-free for four years.

\section{CONFLICTS OF INTEREST}

None declared.

\section{AUTHOR CONTRIBUTIONS}

Concept - H.D., F.D., A.Ç., L.D.; Planning and Design H.D., F.D., A.Ç., L.D.; Supervision - H.D., F.D., A.Ç., L.D.; Funding -; Materials -; Data Collection and/or Processing - H.D.; Analysis and/or Interpretation - F.D.; Literature Review - F.D.; Writing - H.D.; Critical Review L.D. 


\section{YAZAR KATKILARI}

Fikir - H.D., F.D., A.Ç., L.D.; Tasarım ve Dizayn - H.D., F.D., A.Ç., L.D.; Denetleme - H.D., F.D., A.Ç., L.D.; Kaynaklar -; Malzemeler -; Veri Toplama ve/veya İşleme H.D.; Analiz ve/veya Yorum - F.D.; Literatür Taraması F.D.; Yazıyı Yazan - H.D.; Eleştirel İnceleme - L.D.

\section{REFERENCES}

1. Kransdorf MJ. Benign soft-tissue tumors in a large referral population: distribution of specific diagnoses by age, sex, and location. AJR Am J Roentgenol 1995; 164:395-402. [CrossRef]

2. Brown LR, Reiman HM, Rosenow EC 3rd, Gloviczki PM, Divertie MB. Intrathoracic lymphangioma. Mayo Clin Proc 1986; 61:882-92. [CrossRef]

3. Misthos P, Sepsas E, Kokotsakis I, Skottis I. Asymptomatic solitary mediastinal cystic lymphangioma: a rare entity. Asian Cardiovasc Thorac Ann 2006; 14:476-8. [CrossRef]

4. Saleiro S, Magalhães A, Moura CS, Hespanhol V. Mediastinal cystic lymphangioma. Rev Port Pneumol 2006; 12:731-5. [CrossRef]

5. Yildirim E, Dural K, Kaplan T, Sakinci U. Cystic lymphangioma: report of two atypical cases. Interact Cardiovasc Thorac Surg 2004; 3:63-5. [CrossRef]

6. Enzinger FM, Weiss SW. Soft tissue tumors. 4th ed. New York: Mosby; 2001; 955-83.

7. Faul JL, Berry GJ, Colby TV, Ruoss SJ, Walter MB, Rosen $G D$, et al. Thoracic lymphangiomas, lymphangiectasis, lymphangiomatosis, and lymphatic dysplasia syndrome. Am J Respir Crit Care Med 2000; 161:1037-46. [CrossRef]
8. Charruau L, Parrens $M$, Jougon J, Montaudon $M$, Blachère $H$, Latrabe $V$, et al. Mediastinal lymphangioma in adults: CT and MR imaging features. Eur Radiol 2000; 10:1310-4. [CrossRef]

9. Bilgin M, Akçalı Y, Oğuzkaya F, Öktem T. Mediastinal cystic lymphangioma: a rare mediastinal tumour. Turkish Respir J 2004; 5:187-8.

10. Nanson EM. Lymphangioma (cystic hygroma) of the mediastinum. J Cardiovasc Surg (Torino) 1968; 9:447-52.

11. Karakas $O$, Karakas E, Boyaci FN, Yildizhan M, Demir S, Saglam MA, et al. Cervicomediastinal giant cystic hygroma: a case report. J Clin Med Res 2013; 5:61-3.. [CrossRef]

12. Hunt I, Eaton D, Dalal P, Burke M, Anikin V. Minimally invasive excision of a mediastinal cystic lymphangioma. Can J Surg 2009; 52:201-2.

13. Park JG, Aubry MC, Godfrey JA, Midthun DE. Mediastinal lymphangioma: Mayo Clinic experience of 25 cases. Mayo Clin Proc 2006; 81:1197-203. [CrossRef]

14. Flanagan BP, Helwig EB. Cutaneous lymphangioma. Arch Dermatol 1977; 113:24-30. [CrossRef]

15. Souza RJ, Tone LG. Treatment of lymphangioma with alpha-2a-interferon. J Pediatr (Rio J) 2001; 77:139-42. [CrossRef]

16. Reinhardt MA, Nelson SC, Sencer SF, Bostrom BC, Kurachek SC, Nesbit ME. Treatment of childhood lymphangiomas with interferon-alpha. J Pediatr Hematol Oncol 1997; 19:232-6. [CrossRef]

17. Turner C, Gross S. Treatment of recurrent suprahyoid cervicofacial lymphangioma with intravenous cyclophosphamide. Am J Pediatr Hematol Oncol 1994; 16:325-8. 